\title{
SOLUTIONS OF TEACHING AND LEARNING PHYSICAL EDUCATION AT HO CHI MINH CITY COLLEGE OF ECONOMICS, VIETNAM
}

\author{
Bui Huu Phuc ${ }^{11}$, \\ Duong Ngoc Truong2, \\ Nguyen Tri Tai ${ }^{3}$ \\ ${ }^{1}$ Department of National Defense Education and Physical Education, \\ Van Lang University, \\ Vietnam \\ ${ }^{2}$ Faculty of National Defense Education and Physical Education, \\ Sai Gon University, \\ Vietnam \\ ${ }^{3}$ Department of Physical Education, \\ Hochiminh City College of Economics, \\ Vietnam
}

\begin{abstract}
:
Physical education is one of the compulsory courses at Ho Chi Minh City College of Economics. However, students have been observed to be less engaged in physical activities. Therefore, this study aims to investigate the solutions of teaching and learning physical education at this institution. In particular, fifteen solutions are proposed to enhance the quality of teaching and learning physical education.
\end{abstract}

Keywords: solutions, quality, teaching and learning, physical education

\section{Introduction}

In recent years, due to the development of technology, many universities and colleges in Vietnam have constantly reformed and developed in their facilities as well as curriculum. There have been many late teaching methodologies have been applied in various institutions. To meet the requirements of the development, Ho Chi Minh City College of Economics has also carried out some changes in its training process. Although physical education is usually considered as a secondary subject, the college rector board has required the department of physical education to improve its teaching and learning quality. However, in reality, it is very hard for the teaching staff to improve their teaching quality due to the poor facilities and the increase in number of students in recent years.

${ }^{i}$ Correspondence: email phuc.bh@vlu.edu.vn 
Hence, it is imperative for the researchers to conduct a study exploring the causes, opportunities and challenges of physical education and proposing possible solutions to enhance the quality of teaching and learning physical education.

\section{Methods}

The data of the study were collected through a questionnaire to students at Ho Chi Minh City College of Economics. The questionnaire aims at finding out students' attitudes of the physical education course at this college and from which some solutions were proposed to enhance the quality of teaching and learning of physical education at the institution.

The study's participants were 371 students who were in the first and second year at Ho Chi Minh City College of Economics. All of them took the physical education courses due to the requirements of their learning program.

\section{Results}

\subsection{Students' attitudes towards physical education course}

The first part of the questionnaire asked students about their preferences on the physical education course. The students' answers were ranged in the five Likert scale from strongly like to strongly dislike. Then the answers were divided into two groups including the positive group (from "strongly like" to "neither like nor dislike") and the negative one (from "dislike" to "strongly dislike"). The collected data were computed and analyzed by the use of Chi-Square. Table 1 below presents the results of this analysis.

Table 1: Students' preference on the physical education course

\begin{tabular}{|c|c|c|c|c|c|c|c|}
\hline \multirow[b]{2}{*}{ Trend } & \multirow[b]{2}{*}{ Level of preference } & \multicolumn{2}{|c|}{ Distribution $(n=317)$} & \multicolumn{2}{|c|}{ Total } & \multicolumn{2}{|c|}{ Comparison } \\
\hline & & $n_{i}$ & $\%$ & $\sum n_{i}$ & $\%$ & $\chi^{2}$ & $\mathrm{p}$ \\
\hline \multirow{3}{*}{ Positive } & Strongly like & 34 & 10,7 & & & \multirow{5}{*}{124,12} & \multirow{5}{*}{$<0.05$} \\
\hline & Like & 88 & 27,8 & 243 & 76,7 & & \\
\hline & Neither like nor dislike & 121 & 38,2 & & & & \\
\hline \multirow{2}{*}{ Negative } & Dislike & 60 & 18,9 & \multirow{2}{*}{74} & \multirow{2}{*}{23,3} & & \\
\hline & Strongly dislike & 14 & 4,4 & & & & \\
\hline
\end{tabular}

Table 1 indicates that the number of students holding positive attitudes towards the physical education courses surpassed the ones who held negative preference $\left(\chi^{2}>\chi^{2}\right.$,.05, $\mathrm{P}<0.05)$. 


\subsection{Students' difficulties when taking physical education courses}

Next, students' difficulties when taking physical education courses were explored and analyzed. Their difficulties were classified into subjective and objective types. The results are shown in Table 2 below.

Table 2: Students' difficulties when taking physical education courses

\begin{tabular}{|c|c|c|c|c|c|c|c|}
\hline \multirow{2}{*}{ Category } & \multirow{2}{*}{ Difficulties } & \multicolumn{2}{|c|}{$\begin{array}{c}\text { Distribution } \\
(\mathrm{n}=371)\end{array}$} & \multicolumn{2}{|c|}{ Total } & \multicolumn{2}{|c|}{ Comparison } \\
\hline & & $\mathbf{n}$ & $\%$ & $\sum n_{i}$ & $\%$ & $\chi^{2}$ & $\mathbf{P}$ \\
\hline \multirow{5}{*}{ Subjective } & $\begin{array}{l}\text { Lack of interest in the } \\
\text { physical education course }\end{array}$ & 41 & 11,05 & \multirow{5}{*}{149} & \multirow{5}{*}{40,16} & \multirow{10}{*}{15,23} & \multirow{10}{*}{$<0.05$} \\
\hline & $\begin{array}{l}\text { Being afraid of injuries when } \\
\text { learning the physical education course }\end{array}$ & 21 & 5,66 & & & & \\
\hline & Lack of health and confidence & 27 & 7,28 & & & & \\
\hline & Limited sports ability & 22 & 5,93 & & & & \\
\hline & Lack of time & 38 & 10,24 & & & & \\
\hline \multirow{5}{*}{ Objective } & $\begin{array}{l}\text { Lack of diversity and interests } \\
\text { in the course contents }\end{array}$ & 70 & 18,87 & \multirow{5}{*}{222} & \multirow{5}{*}{59,84} & & \\
\hline & $\begin{array}{l}\text { Lack of sport grounds, equipment } \\
\text { and quality }\end{array}$ & 57 & 15,36 & & & & \\
\hline & $\begin{array}{l}\text { Difficulties in distance and means } \\
\text { of transport }\end{array}$ & 54 & 14,56 & & & & \\
\hline & Lack of lecturers & 14 & 3,77 & & & & \\
\hline & Lack of information on the course & 27 & 7,28 & & & & \\
\hline \multicolumn{2}{|l|}{$\sum$} & 317 & 100 & 317 & 100 & & \\
\hline
\end{tabular}

Table 2 shows that there is a significant difference between the subjective difficulties and

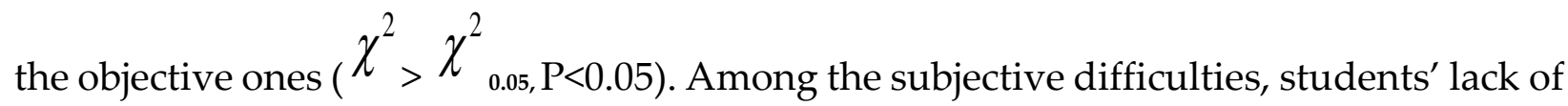
interests in their physical education course at the college was the difficulty got the highest agreement of the students $(11.05 \%)$. In terms of objective difficulties, the respondents found the course's content is not diverse and interesting (18.87\%) was supported the highest.

\subsection{Students' reasons for taking physical education courses}

Reasons for taking the physical education course were examined and the results were shown in Figure 1 below. 


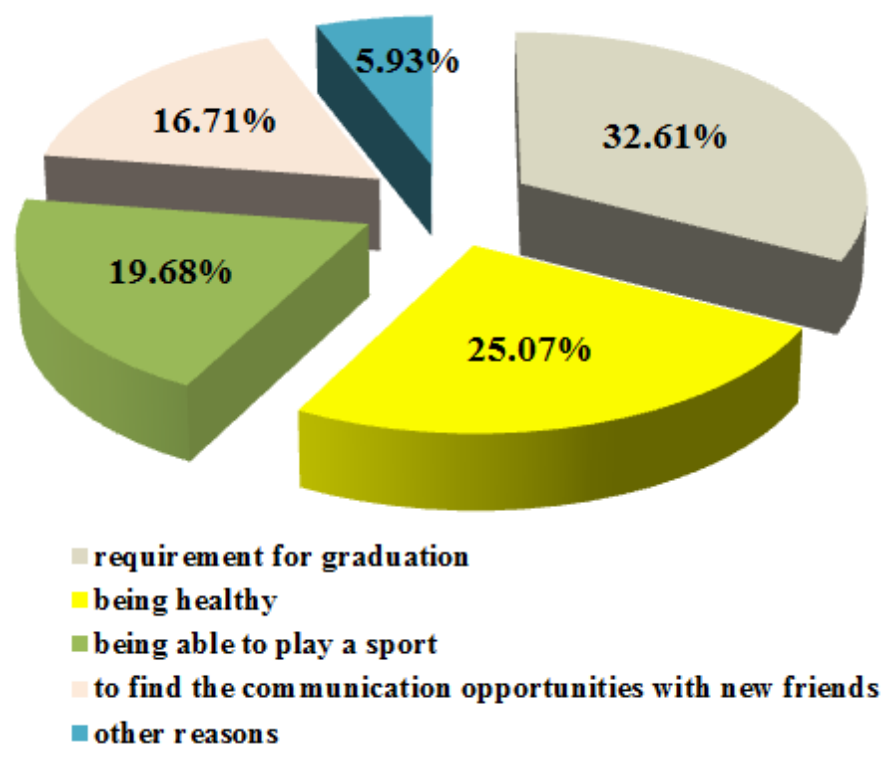

Figure 1: Students' reasons of taking physical education courses

The data in Figure 1 show that the majority of the students admitted that they took the physical education course was it is a "requirement for graduation", accounting for $32.61 \%$. Besides, "being healthy" and "being able to play a sport" accounted for $25.07 \%$ and $19.68 \%$ respectively. $16.71 \%$ of the respondents reported that they took this course "to find the communication opportunities with new friends". Finally, only a small percentage of students $(5.93 \%)$ is related to "other reasons".

\subsection{Students' concerns when taking physical education courses}

The study also examined a few things that the students concern with when taking physical education courses at the institution. The results are shown in Figure 2 below.

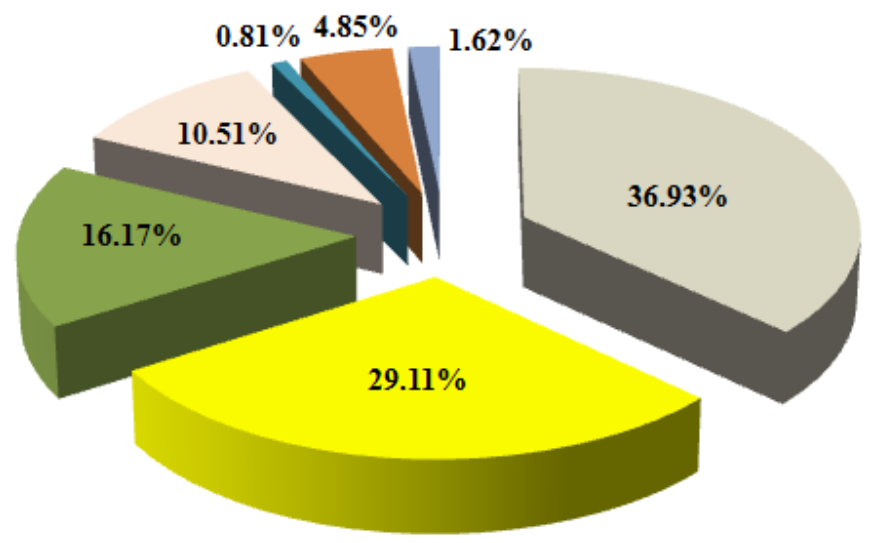

The teaching and learning facilities

The teaching content

- The lecturers' qualifications

The teaching atmosphere

Duration of the courses

Teaching methodology

- Other reasons

Figure 2: Students' concerns when taking physical education courses 
Figure 2 shows that "the teaching and learning facilities" was highly concerned by the respondents (36.93\%). "The teaching content" was the next concern with $29.11 \%$. The factors related to "the lecturers' qualifications" and "the teaching atmosphere" received lower support $(16.17 \%$ and $10.51 \%)$. Only $4.85 \%$ of the students concern about the teaching methodology of their teachers. The findings also show that the students did not care about the "duration of the courses" because only $0.81 \%$ cared about it. Lastly, a small number of students $(1.62 \%)$ concerned about other ideas. In can be concluded that the students' concerns will be helpful for the teaching staff in designing new syllabus for the physical education courses.

\subsection{Students' preference on the kinds of sports included in the physical education courses}

The researchers also examined the students' favorite kinds of sports which they expected to have in their physical education. The results are displayed in Table 3 below.

Table 3: The students' favourite kinds of sports included in the physical education course

\begin{tabular}{|c|c|c|c|c|c|c|c|}
\hline \multirow[b]{2}{*}{ No. } & \multirow[b]{2}{*}{ Preferences of sports } & \multicolumn{2}{|c|}{ Distribution $(\mathrm{n}=371)$} & \multicolumn{2}{|c|}{ Total } & \multicolumn{2}{|c|}{ Comparison } \\
\hline & & $\mathbf{n}_{\mathbf{i}}$ & $\%$ & $\sum n_{i}$ & $\%$ & $\chi^{2}$ & p \\
\hline 1 & Badminton & 107 & 28,84 & \multirow{6}{*}{364} & \multirow{6}{*}{77,63} & \multirow{12}{*}{136,57} & \multirow{12}{*}{$<0.05$} \\
\hline 2 & Football & 47 & 12,67 & & & & \\
\hline 3 & Basketball & 44 & 11,86 & & & & \\
\hline 4 & Karate & 31 & 8,36 & & & & \\
\hline 5 & Volleyball & 30 & 8,09 & & & & \\
\hline 6 & Swimming & 29 & 7,82 & & & & \\
\hline 7 & Table tennis & 22 & 5,93 & \multirow{6}{*}{106} & \multirow{6}{*}{22,37} & & \\
\hline 8 & Chess & 21 & 5,66 & & & & \\
\hline 9 & Shuttlecock & 13 & 3,5 & & & & \\
\hline 10 & Exercise & 12 & 3,23 & & & & \\
\hline 11 & Athletics & 11 & 2,96 & & & & \\
\hline 12 & Other pinions & 4 & 1,08 & & & & \\
\hline & $\sum$ & 371 & 100 & 371 & 100 & & \\
\hline
\end{tabular}

Table 3 indicates that the preferences on the two groups of sports which the students favored are significantly different $\left(\chi^{2}>\chi^{2}{ }_{0.05}, \mathrm{P}<0.05\right)$. The results show that they preferred badminton, football, basketball, karate, volleyball and swimming to other kinds of sports such as table tennis, chess, shuttlecock. The findings are valuable for the teaching staff when determining the kinds of sport to be included in the program.

\subsection{Solutions to enhance the quality of teaching and learning physical education}

From the results of the questionnaire and the reality of teaching and learning physical education at Ho Chi Minh City College of Economics, the researchers would like to recommend 15 solutions as follows. 


\subsubsection{Solutions to the college}

Firstly, the college should issue documents and regulations on functions and responsibility of physical education training.

Secondly, a qualified teaching staff should be recruited to meet the development of the college in general and the department in particular.

Thirdly, the college should upgrade the teaching and learning facilities for physical education.

Fourthly, the college should hold training courses to enhance the professional expertise of the teaching staff.

Finally, the college should have better curriculum to meet the students' learning needs.

\subsubsection{Solutions to the department of physical education}

The department should frequently examine the curriculum and adjust to enhance the quality of teaching and learning physical education.

The department should encourage the teaching staff to improve their qualifications or attend workshops on teaching methods.

The department also needs to research students' opinions and evaluation on the activity of physical education of the department so that it can be adjusted and improved in time.

The department should diversify extracurricular sports activities, sports clubs, and sports competitions in the college.

Lastly, the department should frequently hold conferences to create a good environment for teachers exchange and learn experiences from each other.

\subsubsection{Solutions to the teaching staff}

First, the teaching staff should master the teaching objectives and regulations of the teaching process.

Second, the teaching staff should enhance their professional expertise in order to meet the development of the society.

Third, the teaching staff should frequently update the teaching methods to adapt to the developing trend of the college.

Fourth, the teaching staff should develop the quality of teaching and learning physical education.

Fifth, the teaching staff should give good environment to enhance motivation for students.

\section{Conclusion}

The current study examined students' attitudes of physical education and some solutions to improve the reality of teaching and learning physical education were proposed. 
The quality of the physical education course at the college basically complies with the regulations on the number of periods in the permanent course; however, the number of sports clubs and students' time of extracurricular activities is limited. The facilities and equipment serving the physical education course are restricted and mainly rented, so it is difficult to organize the extracurricular sports clubs. The results of the students after finishing the course are quite high. In addition, most of the students like the physical education course. The students have the needs and motivations to study and play their favorite sports. Finally, the schoolboard has not paid much attention to the activity of physical education.

In summary, the researchers have proposed fifteen solutions to the college, to the department of physical education and the teaching staff.

\section{Conflict of Interest Statement}

The authors declare no conflicts of interests.

\section{About the Authors}

Bui Huu Phuc is head of National Defense Education Department, Van Lang University. He mainly delivers classes in National Defense Education.

Duong Ngoc Truong is Dean of Faculty of National Defense Education and Physical Education, Sai Gon University, Vietnam.

Nguyen Tri Tai is lecturer of Department of Physical Education, Ho Chi Minh City College of Economics, Vietnam.

\section{References}

Ministry of Culture, Sports and Tourism (2012), Circular No. 08/2012/TT-BVHTTDL, dated September 10, 2012, Regulating on the content of assessment and development in sports.

Ministry of Education and Training (2006), Decision No. 25/2006/QD-BGDĐT, dated June 26, 2006 of the Minister of Education and Training. On the promulgation of "Regulations on formal university and college training according to the annual system".

Nguyen Tan Chieu (2007), Some solutions to improve the quality of professional intermediate training in Ho Chi Minh City, Master thesis, Ho Chi Minh City University of Sports.

Hoang $\mathrm{Ha}$ (2014), Assessing the reality and proposing solutions to improve the effectiveness of physical education work of the National University of Ho Chi Minh City. Ho Chi Minh City, Scientific Research Project at University of Social Sciences \& Humanities, Ho Chi Minh City. 
Nguyen Duc Thanh. (2010). Developing the content and form of organizing extracurricular sports activities for students of some universities in Ho Chi Minh City. PhD thesis, Institute of Sports Science.

Ho Chi Minh City Technical College. Strategic plan for the development of economic colleges in Ho Chi Minh City in the period of 2018 - 2025, with a vision to 2030. be applied to their work. Under the terms of this license, no permission is required from the author(s) or publisher for members of the community to copy, distribute, transmit or adapt the article content, providing a proper, prominent and unambiguous attribution to the authors in a manner that makes clear that the materials are being reused under permission of a Creative Commons License. Views, opinions and conclusions expressed in this research article are views, opinions and conclusions of the author(s). Open Access Publishing Group and European Journal of Physical Education and Sport Science shall not be responsible or answerable for any loss, damage or liability caused in relation to/arising out of conflict of interests, copyright violations and inappropriate or inaccurate use of any kind content related or integrated on the research work. All the published works are meeting the Open Access Publishing requirements and can be freely accessed, shared, modified, distributed and used in educational, commercial and non-commercial purposes under a Creative Commons attribution 4.0 International License (CC BY 4.0). 